\title{
The effect of change from low-roughage to high-roughage diets on rumen fermentation, blood composition and milk fat secretion in the cow
}

\author{
BY J. E. STORRY AND J. D. SUTTON \\ National Institute for Research in Dairying, Shinfield, Reading
}

(Received 25 October 1968-Accepted 21 April 1969)

\begin{abstract}
r. Changing cows from a diet with low hay and high flaked maize content, which depressed milk fat secretion, to a high-roughage diet resulted in increased milk fat secretion and in changes in the pattern of rumen fermentation and in the composition of the blood plasma.

2. During the Ist week following the change in diet the proportions of propionic and valeric acids in the rumen decreased and the proportion of acetic acid increased. These changes in rumen volatile fatty acids were associated with decreases in the concentration of lactic acid, increases in $\mathrm{pH}$ and increases in the rate of breakdown of cotton threads in the ventral sac of the rumen. After I week, only minor fluctuations in the proportions of volatile fatty acids occurred from day to day.

3. The percentage of fat in the milk increased over a period of 3 weeks following the change in diet and, with the exception of linoleic acid which decreased, the yields of all fatty acids in milk progressively increased over this period. The increase in yield of oleic acid was relatively much smaller than the increases in yield of saturated acids.

4. The concentrations in blood plasma of acetic acid and $\beta$-hydroxybutyric acid increased in two cows and, in all cows, saturated triglyceride fatty acids increased, whereas the concentrations of the unsaturated triglyceride fatty acids decreased, during the ist week after change to the high-roughage diet. The recovery in milk fat secretion is discussed in relation to the observed changes in rumen fermentation and blood composition.
\end{abstract}

Earlier studies (Balch, Balch, Bartlett, Hosking, Johnson, Rowland \& Turner, 1955) have shown that reducing the quantity of hay and replacing some of the balanced concentrates by flaked maize in the diet of lactating cows reduces milk fat secretion. This reduced secretion of fat was associated with increased proportions of propionic acid and decreased proportions of acetic acid in the rumen (Balch, Balch, Bartlett, Bartrum, Johnson, Rowland \& Turner, 1955; Storry \& Rook, 1966) and also with decreased concentrations in blood plasma of the milk fat precursors acetic acid, $\beta$ hydroxybutyric acid and triglyceride (Storry \& Rook, 1965). However, the infusion of acetic and butyric acids into the rumen of cows receiving these low-roughage diets did not always restore milk fat secretion (Stoddard, Allen \& Peterson, 1949; Tyznik \& Allen, I95 I Balch \& Rowland, I959; Jorgensen, I964; Stanley, Morita \& Ueyama, 1964; Storry \& Rook, I966), and on changing from low-roughage to high-roughage diets full recovery in milk fat secretion was not obtained until some 2 or 3 weeks after the recovery of normal patterns of fermentation in the rumen (Balch, Balch, Bartlett, Cox \& Rowland, 1952; King \& Hemken, 1962; Storry \& Rook, 1965, 1966), suggesting that factors other than changes in the proportion of rumen volatile fatty acids may be involved in the low milk fat syndrome. This possibility has recently received further support. The feeding of low-roughage diets to cows has been shown to affect the 
composition of plasma lipids (Davies \& Sachan, 1966; McCarthy, Dimick \& Patton, I 966 ) and the concentration of precursors and the activity of enzymes in adipose and mammary tissues (Opstvedt, Baldwin \& Ronning, r967; Baldwin \& Cheng, 1968) in a way which suggests that with such diets lipid metabolism may be directed towards the deposition of body fat rather than the secretion of milk fat.

In the present experiments we have examined simultaneously and in more detail than previously the effects of changing cows from a low-roughage to a normal diet on rumen fermentation, the composition of blood and the secretion of milk fat to obtain further information on the factors involved in the low fat syndrome.

\section{EXPERIMENTAL}

Animals and their management. Three Friesian cows, Balsam, Brilliant and Northumbria, with permanent rumen fistulas and in their 2nd month of lactation were used. Their daily diet was progressively changed over a period of 23 to 46 days from a control diet of $8 \mathrm{~kg}$ hay and $8 \mathrm{~kg}$ concentrate cubes to a 'low-roughage' diet in which flaked maize was substituted for part of the hay and concentrates. The final proportions of hay, concentrates and flaked maize in the low-roughage diet were varied for each cow until a pronounced depression in milk fat content to less than $2 \%$ occurred. Hay, concentrates and flaked maize were fed respectively at I, I, 9 (Balsam), I, 4, 6 (Brilliant) and I, 6, 4 (Northumbria) $\mathrm{kg}$ per day. The animals were maintained on the appropriate low-roughage diet for 7-12 days after which time the diet was changed abruptly to the original high-roughage diet which was fed until values for the concentration of milk fat returned to normal.

Sampling and methods of analysis. Milk yields were recorded and samples of milk taken at each milking. Daily composite samples were prepared and analysed for fat content by the Gerber method (British Standards Institution, 1955) and for fatty acid composition of the milk fat by gas chromatography (Storry, Rook \& Hall, 1967). On certain days at intervals throughout the experiment samples of rumen liquor were taken, by aspiration, from the centre of the ventral sac of the rumen at about $\mathrm{I}, 3$ and $7 \mathrm{~h}$ after the morning feed. The $\mathrm{pH}$ was measured immediately and the samples were then stored at $-17^{\circ}$ until analysed for the total concentration and molar proportions of volatile fatty acids by gas chromatography (Sutton \& Johnson, 1969) and for the concentration of lactic acid (Elsden \& Gibson, I954). Cellulose digestion was assessed by determining the loss in weight of cotton threads placed in the bottom of the ventral sac of the rumen for 24 and $48 \mathrm{~h}$ (Campling, Freer \& Balch, 196r).

On the same days as rumen samples were taken blood was also sampled from the jugular vein, using an indwelling polythene cannula, at 8.00 , I0.00, I2.00, I 4.00, 16.00 and $18.00 \mathrm{~h}$. Daily composite samples were prepared from the separated plasmas and they were analysed for glucose (Huggett $\&$ Nixon, 1957), $\beta$-hydroxybutyric acid (Reid, I960) and volatile fatty acids (Storry \& Millard, 1965). Total lipid was also extracted from the plasma samples and the triglyceride content and composition determined by thin-layer and gas chromatography as previously described (Storry, Tuckley \& Hall, 1969). 


\section{RESULTS}

\section{Yield and composition of milk fat}

The effects of the change in diet on the fatty acid composition of the milk fat are given in Table I and on the fat content and yields of the major acids in milk in Figs. I3. The milk fat from cows on the low-roughage diets contained higher proportions of unsaturated $\mathrm{C}_{16}$ and $\mathrm{C}_{18}$ acids and lower proportions of all major saturated acids than that of cows on the high-roughage diets. Following the return to the highroughage diet, the yields of $\mathrm{C}_{4}$ to $\mathrm{C}_{18}$ saturated acids increased about threefold; the yield of oleic acid, however, increased by only about $40 \%$ and the yield of linoleic acid actually decreased.

Table I. The percentage of major fatty acids in milk fat from three cows during the last 4 days of each feeding period

\begin{tabular}{|c|c|c|c|c|c|c|}
\hline \multirow[b]{2}{*}{ Fatty acid* } & \multicolumn{2}{|c|}{ Balsam } & \multicolumn{2}{|c|}{ Brilliant } & \multicolumn{2}{|c|}{ Northumbria } \\
\hline & Low-hay & High-hay & Low-hay & High-hay & Low-hay & High-hay \\
\hline $4: 0$ & $2 \cdot 6$ & $2 \cdot 6$ & $\mathrm{I} \cdot 5$ & $2 \cdot 6$ & $1 \cdot 7$ & $3 \cdot 3$ \\
\hline $6: 0$ & $I \cdot 2$ & $1 \cdot 9$ & $1 \cdot 0$ & $\mathbf{r} \cdot 8$ & 0.8 & $\mathrm{I} \cdot 9$ \\
\hline $8: 0$ & $1 \cdot 9$ & $1 \cdot 4$ & 0.6 & 0.9 & 0.6 & $I \cdot I$ \\
\hline $10: 0$ & $2 \cdot 4$ & 3.8 & $2 \cdot \mathbf{Y}$ & $3 \cdot I$ & $I \cdot 7$ & $3 \cdot 0$ \\
\hline $12: 0$ & $4^{\cdot I}$ & 6.9 & $4 \cdot 0$ & $4 \cdot 9$ & $3 \cdot 4$ & $4 \cdot 9$ \\
\hline I $4: 0$ & $12 \cdot 7$ & 14.7 & II'3 & $13 \cdot 8$ & 10.6 & I $4 \cdot 5$ \\
\hline I $5: 0$ & $\mathrm{I} \cdot \mathbf{2}$ & $I \cdot O$ & $I \cdot 4$ & $1 \cdot 3$ & $\mathbf{x} \cdot 7$ & 0.8 \\
\hline I6:0 & 25.4 & 30.9 & $25 \cdot 5$ & $27 \cdot 5$ & $26 \cdot I$ & $37 \cdot 6$ \\
\hline $16: 1$ & $2 \cdot 8$ & $I \cdot 4$ & $3 \cdot 9$ & $2 \cdot 0$ & $3 \cdot 9$ & $2 \cdot 6$ \\
\hline I8 :0 & $3 \cdot 5$ & $8 \cdot 3$ & $4 \cdot 9$ & $8 \cdot 7$ & $4 \cdot 0$ & $6 \cdot 1$ \\
\hline $18: 1$ & $33^{\circ} 0$ & $21 \cdot 4$ & $33 \cdot 5$ & $26 \cdot I$ & $33 \cdot I$ & $17 \cdot 9$ \\
\hline I $8: 2$ & $5 \cdot 7$ & $I \cdot 6$ & $3 \cdot 7$ & I.4 & $6 \cdot 7$ & 0.8 \\
\hline
\end{tabular}

* Number of carbon atoms and number of double bonds (Farquhar, Insull, Rosen, Stoffel \& Ahrens 1959).

Table 2. Effect of changing three cows from a low-roughage to a high-roughage diet on the percentage change in weight of cotton threads kept in the rumen for 24 or $48 \mathrm{~h}$

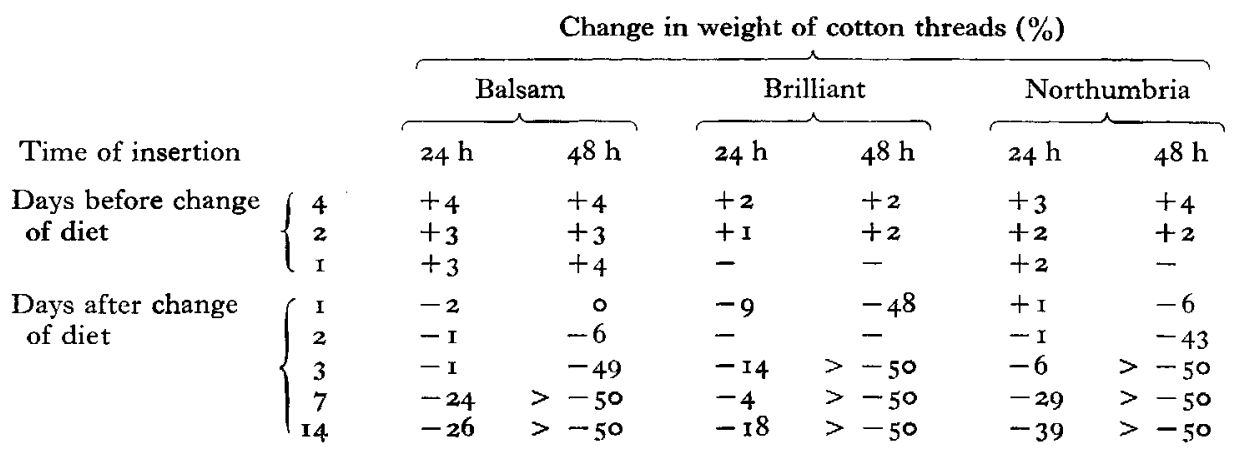


Milk

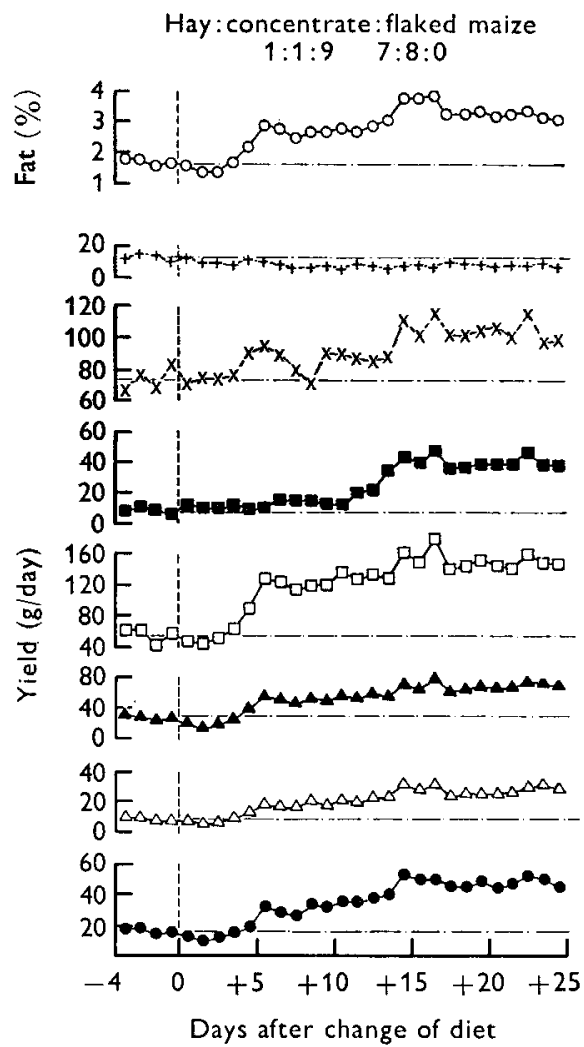

Rumen

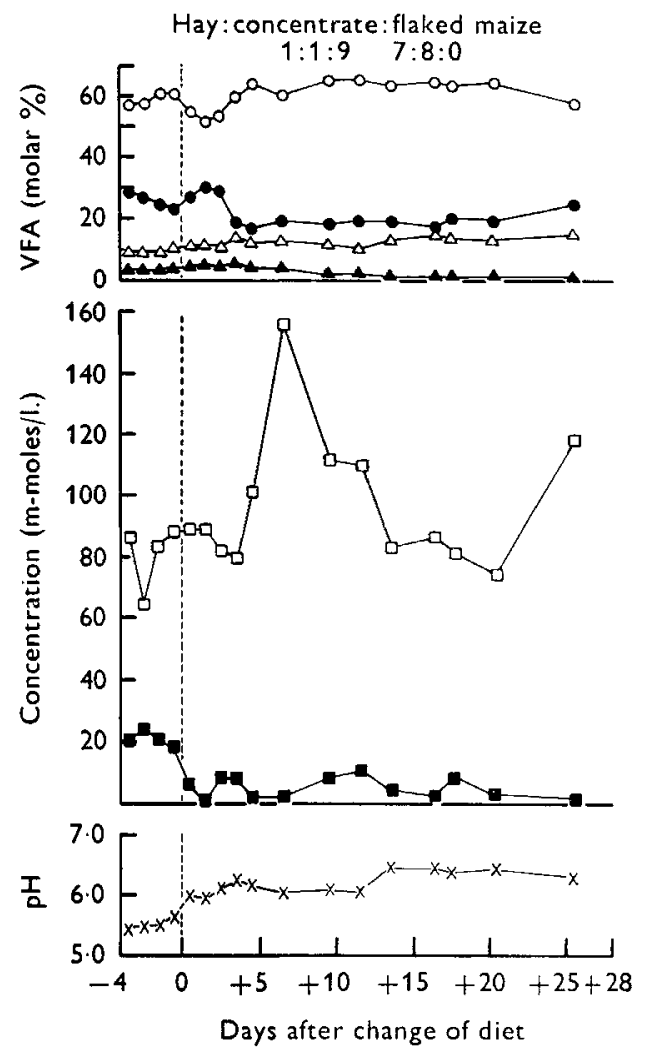

Fig. 1. Effects of changing cow Balsam from a low-roughage to a high-roughage diet on the concentration of fat $(O-O)$ and the yields of $C_{4: 0}-C_{10: 0}(--), C_{12: 0}(\triangle-\triangle), C_{14: 0}$ (A-A), $\mathrm{C}_{18: 0}(\square-\square), \mathrm{C}_{18: 0}(\square-\square), \mathrm{C}_{18: 1}(x-x)$ and $\mathrm{C}_{18: 2}(+-+)$ acids in milk; on the $\mathrm{pH}$ of the rumen $(x-x)$; and on the concentration of lactic acid $(\square-\square)$, and total volatile fatty acids $(\square-\square)$ and on the molar proportions of acetic $(\bigcirc-O)$, propionic $(\bullet-\odot)$, butyric $(\triangle-\triangle)$ and valeric $(\boldsymbol{\Delta}-\boldsymbol{\Delta})$ acids in the rumen.

\section{Composition of rumen digesta}

The effects of changing from the low-roughage to the high-roughage diet on the concentration of lactic acid, on the concentrations and molar ratios of volatile fatty acids and on the $\mathrm{pH}$ in the rumen are given in Figs. $\mathrm{I}-3$. The effects of the change in diet on the rate of breakdown of cotton threads in the rumen are given in Table 2. Although the magnitude of the changes in these values varied from cow to cow the overall trends were similar for all animals. The concentrations of lactic acid and the proportions of propionic and valeric acids decreased and the $\mathrm{pH}$ and proportion of acetic acid increased, to values typical for high-roughage diets, within $5^{-7}$ days of abruptly changing the diet. No breakdown of cotton threads occurred on the lowroughage diet but following the change in diet the rate of breakdown of cotton threads rapidly increased so that, 3 days after the change in diet threads, were at least $50 \%$ digested within $48 \mathrm{~h}$. 

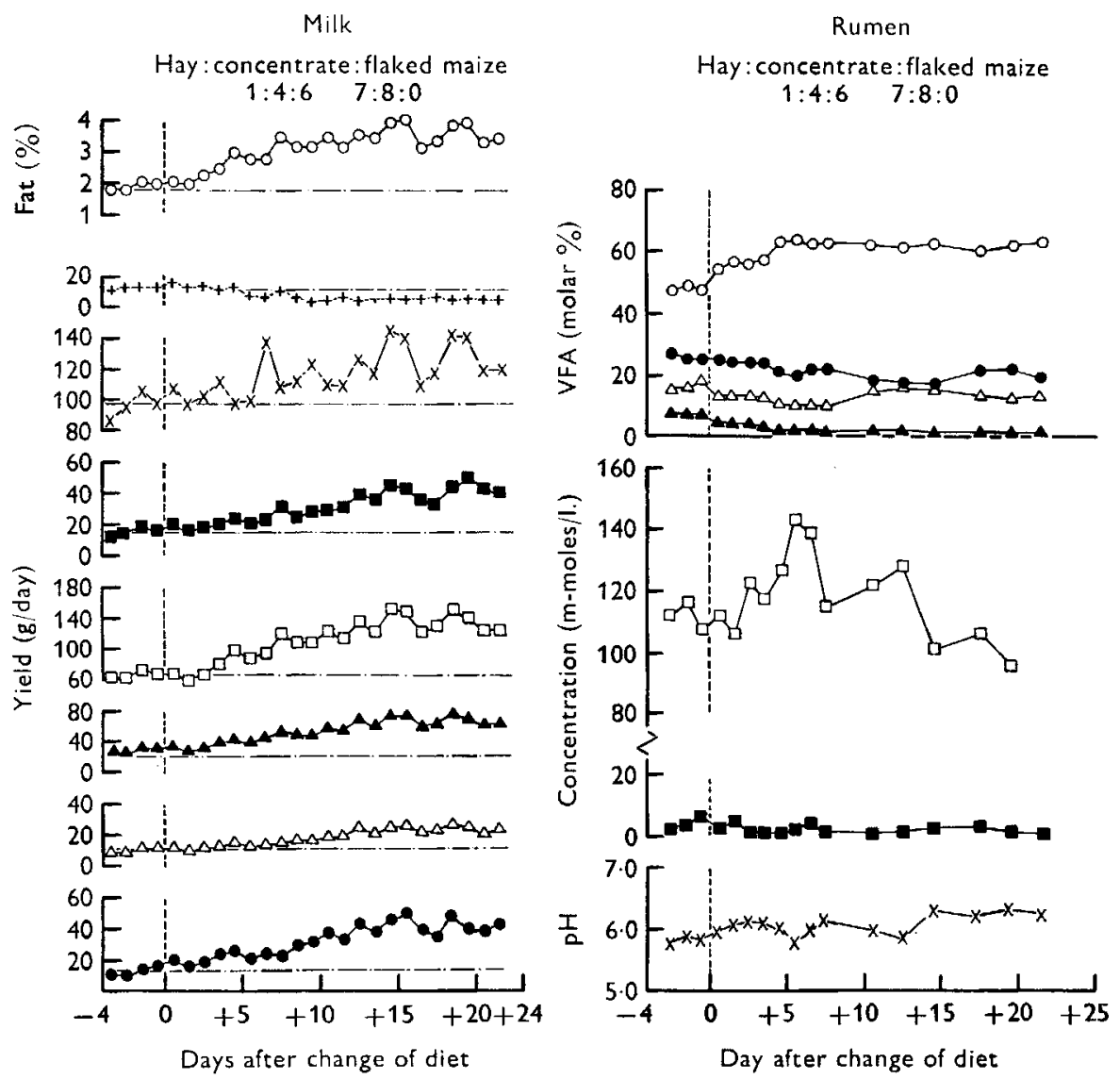

Fig. 2. Effects of changing cow Brilliant from a low-roughage to a high-roughage diet on the concentration of fat $(O-O)$ and the yields of $C_{4: 0}-C_{10: 0}(--), C_{12: 0}(\triangle-\triangle), C_{14: 0}(\Delta-\Delta)$, $\mathrm{C}_{16: 0}(\square-\square), \mathrm{C}_{18: 0}(\square-\square), \mathrm{C}_{18: 1}(x-x)$ and $\mathrm{C}_{18: 2}(+-+)$ acids in milk; on the pH of the rumen $(x-x)$; and on the concentration of lactic acid ( $(-\square)$, and total volatile fatty acids $(\square-\square)$ and on the molar proportions of acetic $(O-O)$, propionic $(\Theta-O)$, butyric $(\triangle-\triangle)$ and valeric $(\boldsymbol{\Delta}-\boldsymbol{\Delta})$ acids in the rumen.

\section{Composition of blood plasma}

Changes in the concentrations of milk fat precursors in the blood plasma of cows changed from the low-roughage to the high-roughage diet are given in Tables $3^{-5}$ for each of the three cows. The concentrations of acetic acid, and $\beta$-hydroxybutyric acid in two cows (Balsam and Northumbria) increased on changing from the lowroughage to the high-roughage diet. Changes in the concentration of plasma glucose and triglycerides were variable and showed no particular trend. However, the fatty acid composition of the plasma triglycerides was markedly altered in all cows, and on the low-roughage diet they contained higher proportions of the unsaturated and lower proportions of the saturated acids together with up to $5 \%$ of unknown components. These changes in composition gave increased concentrations of $C_{12}$ to $C_{18}$ saturated acids and decreased concentrations of $\mathrm{C}_{18}$ unsaturated acids in blood plasma following the change from a low-roughage to a high-roughage diet. 
Milk

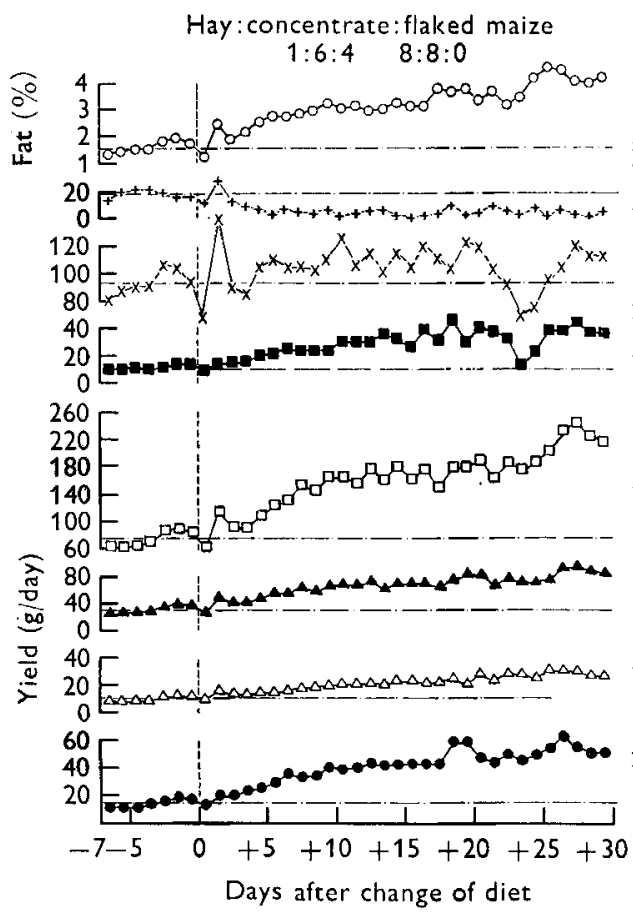

Rumen

Hay: concentrate:flaked maize $1: 6: 4 \quad 8: 8: 0$

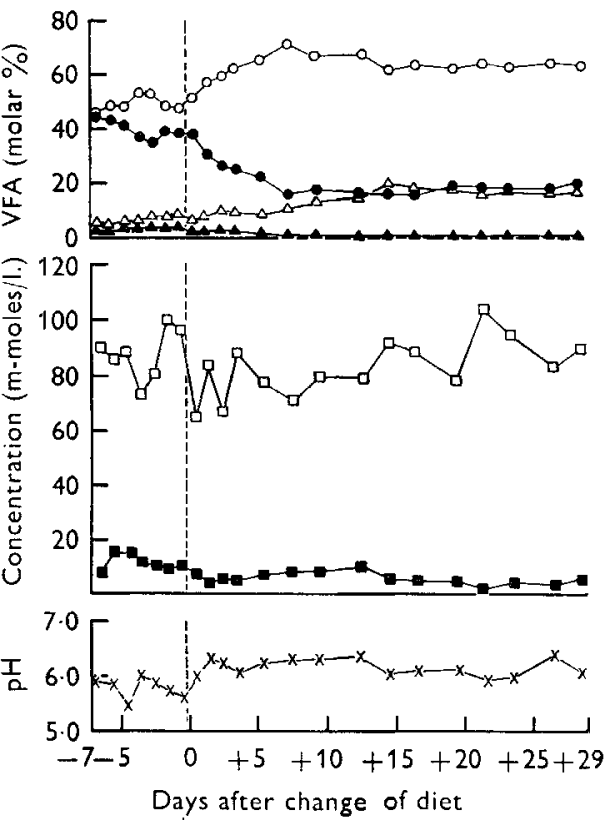

Fig. 3. Effects of changing cow Northumbria from a low-roughage to a high-roughage diet on the concentration of fat $(O-O)$ and the yields of $C_{4: 0}-C_{10: 0}(--O), C_{12: 0}(\triangle-\triangle), C_{14: 0}$ $(\Delta-\Delta), C_{16: 0}(\square-\square), C_{18: 0}(\square-\square), C_{18: 1}(x-x)$ and $C_{18: 2}(+-+)$ acids in milk; on the pH of the rumen $(x-x)$; and on the concentration of lactic acid $(\square-\square)$, and total volatile fatty acids $(\square-\square)$ and on the molar proportions of acetic $(O-O)$, propionic (-O), butyric $(\triangle-\triangle)$ and valeric $(\Delta-\Delta)$ acids in the rumen.

\section{DISCUSSION}

Although the ratio of dietary components on the low-roughage diet varied considerably between cows, a severe fall in milk fat content, to at least half normal values, was observed in all cows. The changes in composition of milk, blood plasma and rumen digesta which accompanied the change from a low-roughage to a high-roughage diet fully confirm the findings of previous experiments (Storry \& Rook, 1965, 1966). In the rumen there were progressive increases in the proportions of acetate and decreases in the proportions of propionate and valerate during the first $5^{-7}$ days following the change in diet. Changes in the proportion of butyrate were less uniform, two animals showing an increase and the third a decrease. These changes in the pattern of rumen fermentation were associated with a rapid increase in cellulolytic activity as reflected by the increased digestion of cotton threads during the first few days after the change in diet.

The change in proportions of rumen volatile fatty acids were associated with increased concentrations in blood plasma of acetic acid and of $\beta$-hydroxybutyric acid in two of the three cows; both acids are used by the mammary gland for synthesis of 


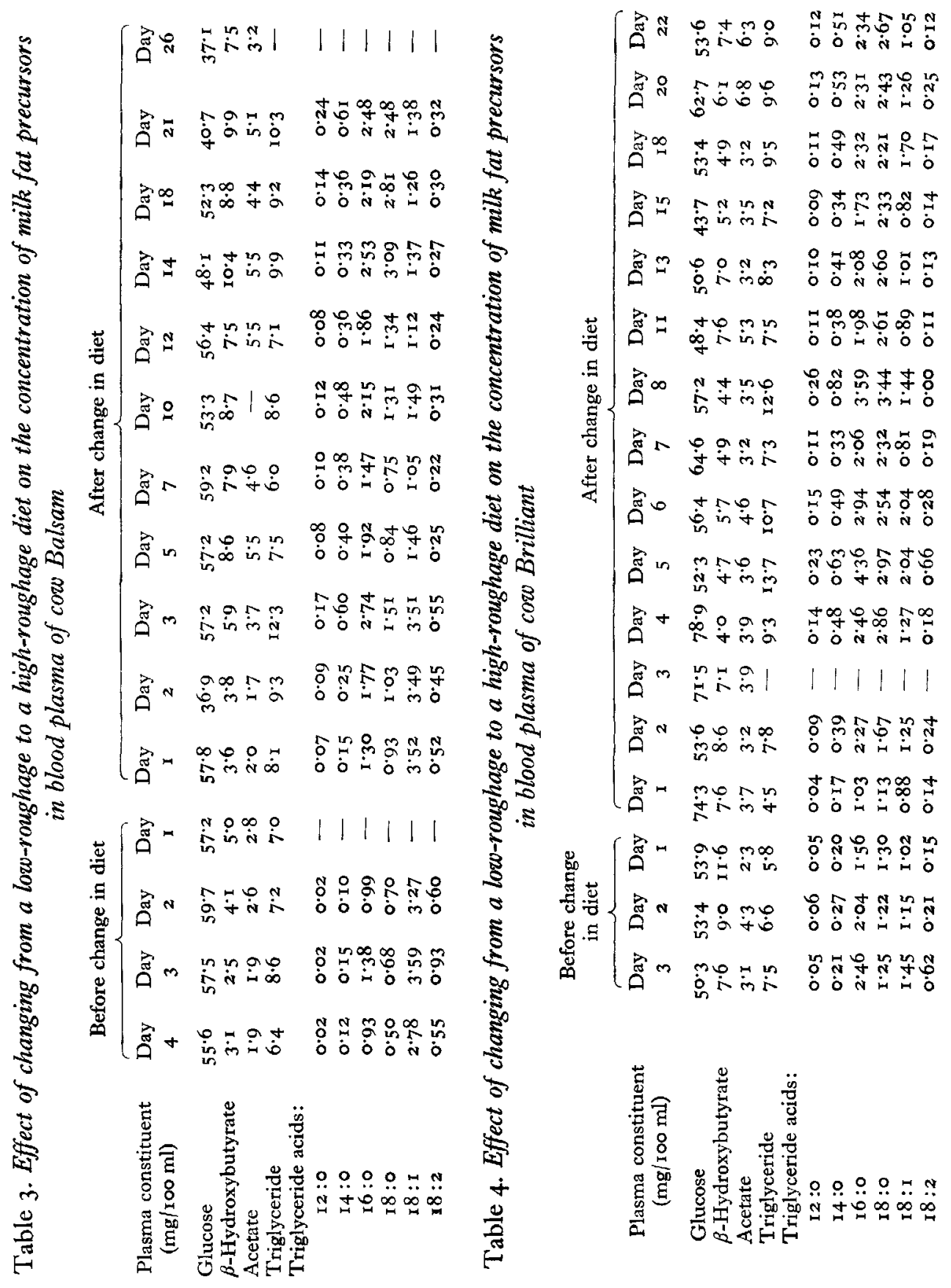




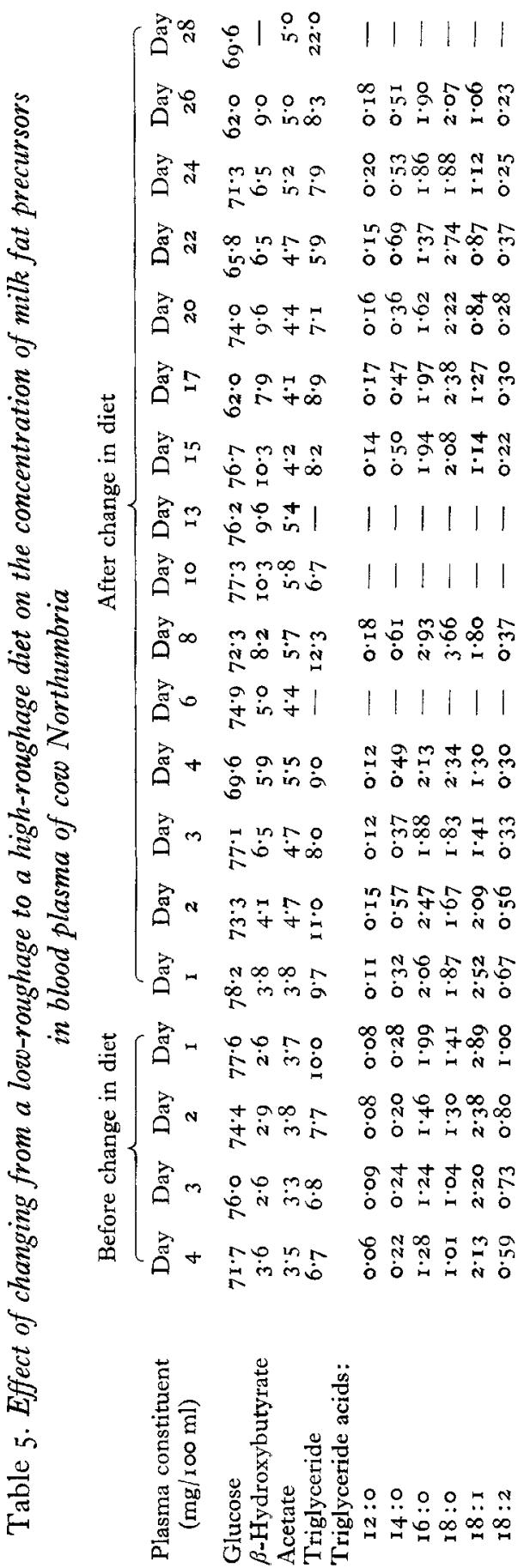


$\mathrm{C}_{4}-\mathrm{C}_{16}$ acids in milk (Barry, 1964 ). Also concentrations of saturated acids in the plasma triglycerides increased and concentrations of unsaturated acids decreased on changing from the low-roughage to the high-roughage diet. Similar changes in the composition of plasma triglycerides of cows on low-roughage diets, including the presence of several unknown components, have also been observed by other workers (McCarthy et al. 1966; Davies \& Sachan, 1966). The higher proportions and concentrations of oleic and linoleic acids in the plasma triglycerides on the low-roughage diet probably arose from the greater dietary intake of the acids from the flaked maize. On the lowroughage diet the intake of oleic and linoleic acids increased by 30 and $20 \%$ respectively. With high-roughage diets linoleic acid is effectively hydrogenated in the rumen before its absorption from the digestive tract (Bath \& Hill, 1967) and even when the diet includes as much as $8 \%$ red palm oil, which contains a large proportion of linoleic acid, the yield of linoleic acid in milk is not increased (Storry, Hall \& Johnson, I968). However, in the present experiments the composition of the plasma triglycerides indicated that hydrogenation of the large dietary intake of unsaturated $\mathrm{C}_{18}$ acids was less efficient on the low-roughage diet. This supports our earlier postulation, based on changes in milk fatty acid composition, that hydrogenation in the rumen is reduced on low-roughage diets (Storry \& Rook, 1965 ). Further support is also provided by the findings that hydrogenation of dietary unsaturated acids in the rumen is less in calves (Viviani, Borgatti, Monetti \& Mordenti, 1967) and sheep (Tove \& Matrone, I962) when they are fed all-concentrate as compared with hay and concentrate diets.

In view of the absence of protozoa in the rumen of cows with depressed milk fat observed by Chalupa, Odell, Kutches \& Lauker (1967) and of the known role of these organisms, particularly the oligotrichs, in the hydrogenation of unsaturated acids in the rumen (Wright, 1959; Klopfenstein, Purser \& Tyznik, 1966; Lough, 1968; Chalupa \& Kutches, 1968), it is possible that a reduction in protozoa as well as changes in the bacterial flora may have occurred in the present experiments.

In milk fat the short-chain acids (four to ten carbon atoms) are derived entirely by synthesis within the mammary gland from acetic and $\beta$-hydroxybutyric acids, the long-chain acids (eighteen carbon atoms) from the triglycerides of the low-density $\beta$-lipoproteins of plasma and the intermediate acids (twelve to sixteen carbon atoms) from both these sources (Barry, 1964). Of the $\mathrm{C}_{18}$ acids in milk fat, however, oleic acid is derived both directly from the oleic acid and indirectly by intramammary dehydrogenation of the stearic acid (Lauryssens, Verbeke \& Peeters, I96r; Annison, Linzell, Fazakerley \& Nichols, 1967 ) of the blood plasma lipoprotein triglycerides. Thus the greater yields of the saturated acids in milk of cows on the high-roughage diets were associated in Balsam and Northumbria with higher concentrations of their respective precursors in blood plasma. This relationship was also apparent in Brilliant for the long-chain, but not for the short-chain saturated fatty acids in milk. The lower yields of linoleic acid when the animals were on the high-roughage diet were also associated with lower concentrations of this acid in blood plasma but the yields of oleic acid on the high-roughage diet increased in spite of a fall in concentration of oleic acid in the blood plasma triglycerides. In view of the known desaturation of stearic to oleic acid discussed above, it is probable that the greater yield of oleic acid in the milk of cows on 
the high-roughage diet was derived, by this pathway, from the increased concentration of stearic acid in the plasma triglycerides.

The depressed fat content of the milk resulted from a decreased secretion of all acids except linoleic acid and showed that the processes of synthesis within the mammary gland and of uptake from the blood plasma of the triglyceride fatty acids, which contribute to the formation of milk fat, are both affected in the same direction by the feeding of low-roughage diets. Since the increased yields of fatty acids in milk following the changes to high-roughage diets were generally associated with increased concentrations in blood plasma of the respective precursors, it is tempting to conclude that the reduced synthesis of milk fat on the low-roughage diets resulted from a reduction in the supply to the mammary gland of the necessary precursors. Factors which might affect the supply of precursors are: the changed proportions of volatile fatty acids in the rumen, changes in the intake of dietary lipid and in its metabolism in the rumen, and possibly also increased synthesis and deposition of long-chain fatty acids in adipose tissue (Opstvedt et al. 1967). On changing from the low-roughage to the high-roughage diet, adaptive changes in the rumen occurred rapidly and apparently were largely complete within I week or less. Changes in the concentration of blood metabolites were more variable and tended to be more protracted following the change in diet but the major changes seemed to be complete within about Io days, whereas in milk the yield of fatty acids continued to increase for about 3 weeks. Although no direct estimates of the amounts of metabolites absorbed from the digestive tract were made in the present experiments, the changes in rumen fermentation and blood composition occurred much more rapidly than the recovery in yield of milk fatty acids. This protracted recovery in milk fat secretion in relation to changes in rumen fermentation and blood composition thus lends support to the suggestion of other workers (Opstvedt et al. I967; Baldwin \& Cheng, 1968) that adaptive changes in the activity of enzymes in adipose tissue and mammary gland are also involved in the low milk fat syndrome.

We thank Mr A. J. Hall, Mr B. Tuckley, Mr D. Millard and Mr E. Schuller for skilled technical assistance and Mr V.W. Johnson for care of the experimental animals.

\section{REFERENCES}

Annison, E. F., Linzell, J. L., Fazakerley, S. \& Nichols, B. W. (1967). Biochem. F. 102, 637.

Balch, C. C., Balch, D. A., Bartlett, S., Bartrum, M. P., Johnson, V. W., Rowland, S. J. \& Turner, J. (I955), F. Dairy Res, 22, 270.

Balch, C. C., Balch, D. A., Bartlett, S., Cox, C. P. \& Rowland, S. J. (1952). F. Dairy Res. I9, 39.

Balch, C. C., Balch, D. A., Bartlett, S., Hosking, Z. D., Johnson, V. W., Rowland, S. J. \& Turner, J. (1955). F. Dairy Res. 22, 10.

Baich, C. C. \& Rowland, S. J. (1959). F. Dairy Res, 26, 162.

Baldwin, R. L. \& Cheng, W. (1968). Fedn Proc. Fedn Am. Socs exp. Biol. 27, 558.

Barry, J. M. (1964). Biol. Rev. 39, 194.

Bath, I. H. \& Hill, K. J. (1967). F. agric. Sci., Camb. 68, r39.

British Standards Institution (1955). British Standard 696: Part 1, p. 7. London: British Standards Institution.

Campling, R. C., Freer, M. \& Balch, C. C. (I96r). Br. J. Nutr. I5, 53 I. 
Chalupa, W. \& Kutches, A. J. (1968). F. Anim. Sci. 27, 1502.

Chalupa, W., Odell, G. D., Kutches, A. J. \& Lauker, R. (1967). J. Dairy Sci. 50, 1002.

Davies, C. L. \& Sachan, D. S. (1966). J. Dairy Sci. 49, 1567.

Elsden, S. R. \& Gibson, Q. H. (1954). Biochem F. 58, r 54 .

Farquhar, J. W., Insull, W. Jr, Rosen, P., Stoffel, W. \& Ahrens, E. H. Jr (1959). Nutr. Rev. r7, Suppl.

Huggett, A. St. G. \& Nixon, D. A. (1957). Biochem. 7. 66, 12 P.

Jorgensen, N. A. (1964). Diss. Abstr. 25, 2128.

King, R. L. \& Hemken, R. W. (1962). F. Dairy Sci. 45, 1336.

Klopfenstein, T. J., Purser, D. B. \& Tyznik, W. J. (1966). F. Anim. Sci. 25, 765.

Lauryssens, M., Verbeke, R. \& Peeters, G. (1961). F. Lipid Res. 2, 383.

Lough, A. K. (I968). Proc. Nutr. Soc. 27, 30A.

McCarthy, R. D., Dimick, P. S. \& Patton, S. (1966). F. Dairy Sci. 49, 205.

Opstvedt, J., Baldwin, R. L. \& Ronning, M. (1967). F. Dairy Sci. 50, ro8.

Reid, R. L. (1960). Analyst, Lond. 85, 265.

Stanley, R. W., Morita, K. \& Ueyama, E. (1964). F. Dairy Sci. 47, 258.

Stoddard, G. E., Allen, N. N. \& Peterson, W. H. (1949). F. Anim. Sci. 8, 630.

Storry, J. E., Hall, A. J. \& Johnson, V. W. (I 968). Br. F. Nutr. 22, 609.

Storry, J. E. \& Millard, D. (1965). F. Sci. Fd Agric. 16, 4 1 7.

Storry, J. E. \& Rook, J. A. F. (1965). Br. F. Nutr. x9, IоI

Storry, J. E. \& Rook, J. A. F. (1966). Br. F. Nutr. 20, 2 r 7.

Storry, J. E., Rook, J. A. F. \& Hall, A. J. (I967). Br. F. Nutr. 21, 425.

Storry, J. E., Tuckley, B. \& Hall, A. J. (1969). Br. J. Nutr. 23, 157.

Sutton, J. D. \& Johnson, V. W. (1969). F. agric. Sci., Camb. (In the Press.)

Tove, S. B. \& Matrone, G. (1962). F. Nutr. 76, 271.

Tyznik, W. \& Allen, N. N. (r95I). F. Dairy Sci. 34, 493.

Viviani, R., Borgatti, A. R., Monetti, P.G. \& Mordenti, A. (1967). Zentbl. VetMed. r4A, 833.

Wright, D. E. (I959). Nature, Lond. I84, 875 . 